\title{
PERIKLES'İN KARADENIZ SEFERI ÜZERINE YENI BIR YORUM
}

\author{
MUZAFFER DEMIR*
}

Klasik Çağ'da Atina döneminin (M.Ö. 454-404) önemli olaylarından biri de Atina'nın önde gelen devlet adamlarından general Perikles'in Karadeniz Seferidir ${ }^{1}$. Bize Karadeniz Seferi konusunda bilgi veren tek kaynak eskiçağ biyografi yazarı Plutarkhos (M.S. 50-120)'a aittir ve bu sefer ile ilgili iki yeni çalışma yapılmıştur. Birinci çalışmada, Plutarkhos'un seferle ilgili gözlemlerinin yanlıs olduğu ön görülerek, Atinalılar'ın Perikles'in seferi sonucu Karadeniz'e herhangi bir koloni göndermediği ana fikri tartışılır ${ }^{2}$. İkinci çalışmada daha da ileri gidilerek Plutarkhos'un Karadeniz Seferi ile ilgili gözlemlerinin Atina'da Hellen birliği fikrinin çok güçlü olduğu M.Ö. 4.yüzyılda uydurulmuş olabileceği, dolayısı ile Plutarkhos'un Atinalılar'ı bu seferi düzenlemiş gibi göstererek bizleri yanıltuğı öne sürülmektedir Ayrıca bu iki çalışmada yazarlar seferin Atina açısından politik ve ekonomik sonuçlarının önemli olmamasını kendi tartışmalarını desteklemek için kullanmaktadırlar.

Bize göre bu seferin düzenlendiği andaki Atina'nın iç siyasî durumu göz önünde tutulduğunda Plutarkhos'un gözlemlerine bir dereceye kadar hak vermek gerekmektedir. Perikles Atinalılar'ın girişilen seferin gelişim çizgisi üzerine doğal olarak ortaya çıkan bir takım başka siyasî ve ekonomik çıkarlar elde edebileceğinin farkındaydı ve aşağıda açıklanacağı gibi Atinalılar'ın nihayetinde az da olsa bu sefer sonucunda bazı pratik faydalar elde ettiği görülmektedir. Fakat başlangıçta Perikles'i bu seferi düzenlenmeye iten temel etken, Atina devletinin iç siyasî sorunundan kaynaklanan ilgiyi başka bir tarafa çekme arzusu olabilirdi.

* Muğla Üniversitesi Fen-Edebiyat Fakültesi Tarih Bölūmū.

${ }^{1}$ Perikles (M.O. 495-429) Atina demokrasisi ve emperyalizmi arkasındaki itici gũcũ ve ruhu sağlayan devlet adamı ve askerdir. M.Ö. 443 den ölümūne kadar her yıl Atina stratēgosu (generali) seçilmiştir. Parthenon' un inşasını sağlamış ve zamanının entellektüellerinin en yakın dostu olmuştur. Bu konuda inceleme için bk.: C.M Bowra, Periclean Athens, London, 1971.

${ }^{2}$ H.B Mattingly, "Athens and the Black Sea in the fifth century BC", Actes du Ve Symposium de Vani, 1990, eds. O. Lordkipanidze and P. Leveque, Paris, 1996, s.151-157.

${ }^{3}$ G.R Tsetskhladze, "Plutarch, Pericles and Pontus: some thoughts", Actas Del V Simposio Español Sobre Plutarco, 1996, eds. C. Schrader, V. Ramon and J.Vela, Zaragoza, 1997, s.461-466. 
Kesin tarihinin bilinmemesine rağmen, Atinalılar'ın Byzantion ötesine ilk kez donanmalarını gönderdikleri, Perikles'in ünlü Karadeniz Seferi'nin M.Ö. 436/5 yılları civarında düzenlendiği çok muhtemeldir ${ }^{4}$. Plutarkhos Perikles'in Karadeniz Seferi ile ilgili şu görüşlere yer vermektedir:

"Perikles Karadeniz'e büyük ve muhteşem bir şekilde donatılmış bir donanma ile açıldı ve orada Hellen şehirlerine hürmetkâr bir şekilde davranıp müzakere ile onların arzuladığı çeşitli yerel antlaşmalar yaptı. Bu arada Karadeniz çevresindeki komşu barbar devletlerinin kralları ve genç prenslerine sadece Atina askeri gücünü değil, aynı zamanda Atinalılar'ın donanmaları ile kendilerinden emin ve bağımsız bir şekilde Karadeniz'de istedikleri yere seyredebileceklerini ve bu sularda hakimiyeti sağlıyabileceklerini gösterdi. ${ }^{15}$

Bize göre Plutarkhos'un yukarıdaki açıklamasında yer alan iki nokta dikkate alınmalıdır. Bunlardan birincisi ilk cümlede yer alan, Perikles'in Hellen şehirleri ile yerel antlaşmalar yapıp onlara iỳ davrandı̆̆ı bölümdür ki bizce bu Atinalılar'ın seferin gelişimi sürecinde firsatları değerlendirerek elde etmiş oldukları siyasî veya ekonomik çıkarlar hükmünde değerlendirilebilir. Diğer cümle ise Atina İmparatorluğu'nun gücünü Karadeniz ve çevresindeki diğer yeni krallıklara ve prensliklere gösterdiği bölümdür. Siyasî alanda sadece bir güç gösterisinde bulunma arzusuna dayanan bu bölüm ise Perikles'in sefere çıktığı anda kafasında olan asıl niyetine işaret edebilir. Bu seferin düzenlendiği sıradaki Atina'nın iç siyasî durumunun da Perikles'in bir güç gösterisinde bulunma arzusunu desteklediği görülmektedir.

Tarihte her olayın sebebi zamanının şart ve koşulları dikkate alınarak değerlendirilmelidir. Plutarkhos Karadeniz Seferi ile ilgili gözlemlerini verdiği metinden hemen sonraki paragrafta, bu seferin düzenlendiği zamanda Atina'daki iç siyasi gelişmeler ile ilgili olarak şu noktaya işaret etmektedir; "Perikles'in Atina vatandaşlarının tahriklerine göz yummadığı durumlar vardı. Atinalılar o zamanda ellerinde bulunan güç ve zenginlikle sarhoş olup Pers İmparatorluğu'ndan Misır'ı geri alarak bu imparatorluğun hakimiyeti altundaki sulara saldırmaktan söz ettiklerinde, Perikles bu tür maceralara sürüklenmeyi reddetti. Bir çok Atina vatandaşı daha aşırı gidip sonuçlarını düşünmeden Sicilya'y fethetmeyi tutku haline getirmişti. Bu tutku daha sonra Alkibiades ve diğer dēmagagoslar tarafindan alevlendirilmişti. Hatta Kartaca ve Etruria'ya saldırma hayalleri vardı..." ${ }^{6}$.

\footnotetext{
${ }^{4}$ R.Develin, Athenian Officials, 684-321 BC, Cambridge, 1989, s.96 ve Tsetskhladze, a.g.m, s.462.

${ }^{5}$ I. Scott-Kilvert ( trans.), The Rise and Fall of Athens: Nine Lives By Plutarch, London, 1960, Perikles.20.1.

${ }^{6}$ Scott-Kilvert, a.g.e., Perikles.20.5-8
} 
Yukarıdaki metinden anlaşıldı̆̆ı gibi seferin düzenlendiği zamanda Perikles'i dış fetihlere zorlamak için üzerinde Atina halkının büyük bir baskısı vardı. J. de Romilly bu dönemle ilgili olarak şöyle demektedir:"Şehir tamamıyle ilgisiz değildi, fakat bu tasavvur sadece ikinci derecede ve aralıklarla gelen bir aksiyona ilham verdi. Bir çok vatandaş ekonomik yönü hiç mi hiç düşünmeyerek emperyalist bir tutumu benimsedi ve hazineyi doldurmayı düşünenler de parayı sadece diğer fetihler için kullanma niyetindeydi: güç zenginliğe değil, zenginlik güce yolaçt.."7 Yukarıda verilen alıntıda da Plutarkhos, Karadeniz seferinin düzenlendiği dönemde Atinalılar'ın refah ve güç sarhoşluğu içinde olduğunu vurgulamaktadırs. Buna göre ekonomik zenginlik ve siyasî güç içinde bulunan Atina halkının psikolojik olarak daha fazla kontrol etme duygusu içine girmiş olduğu görülmektedir. Muhtemelen seferin düzenlendiği sırada, Atinalılar maddi faydalardan daha çok kendi yaşama biçimleri ve idari yapılarını diğer insanlara empoze etmeyi düşünüyorlard ${ }^{9}$. Çünkü bunlar Atinalılar'a daha büyük bir şöhret sağlayabilir ve saygınlıklarını artturabilirdi. Böylelikle Atinalılar diğer insanları kendileri gibi medenileștirerek psikolojik ve ruhani olarak kendilerini tatmin etmek isteyebilirlerdi ${ }^{10}$. Karadeniz seferinin dü-

7 Thucydides and Athenian Imperialism, Oxford, 1963, s.77.

8 M.Ō. 5.yüzyılın ortalarında Perikles halkçı politikalar izleyerek Attika demelerinde (kōylerinde) yaşayan kitleleri Atina'da yerleşmeye teşvik etmişti. Bunu yapmasının nedenlerinden bir tanesi de bu nüfusun siyaset sahasındaki diğer rakibi Kimon karşısında Perikles'i destekleyecek olmasıydı. Kimon'un zenginliği ve mal varlığı ile fakirlerin sevgisini kazanması karşısında Perikles kamu mallarının fakirlere dağıtılması politikasını izledi. Onlara halk festivalleri için harçlıklar, mahkemede jüri hizmeti için ücretler ve diğer bağışlarla bahşişler vererek Atina'nın tek lideri olmayı başardı. Scott-Kilvert, a.g.e., Perikles.9. M.Ö. 454 yılında Mısır felaketine rağmen kısa sürede kendilerini toparlayan Atinalılar bu yenilgiyi bahane ederek Attika-Delos Deniz Birliği'nin hazinesini Delos'tan Atina'ya taşıdılar ve birlik üyesi devletlerden almış olduklan vergileri kendi amaçları için kullanmaya başladılar. M.Ō. 449 yılında Persler ile Kallias antlaşması yaptığı görūlen Atina, Doğu Akdeniz ve Ege'deki siyasî oteritesini korumakla kalmamıs, bu bōlgelerdeki ekonomik sōmürgeciliğini de giderek arturmışur. Sonuçta Atina halkının M.Ö. 5.yüzyılın ikinci yarısından itibaren Perikles'in desteği ile belli bir refaha ulaştuğı ve Atina hazinesinin Parthenon'un inşası gibi (M.Ō. 447/6) çok büyük inşaat projelerini destekleyebildiği gōrülmektedir. M.Ō. 436/5 ylındaki Karadeniz Seferi sırasındada Atinalılar'ın ekonomik refah ve siyasî güçlerinin doruğuna ulaşmıs olması doğaldır. Thukydides'e göre Atina siyasî ve ekonomik gücünün bu büyüklüğü Spartahlar'ı endişelendirmiş ve M.Ö. 431 yılında Peloponnesos Savaşı'na sebebiyet vermiştir. R. Crawley (trans.), Thucydides, History of the Peloponnesian War, London, 1993, 1.kitap, s. 88, 118. Genel olarak Atina'nın bu durumu ile ilgili çalışmalar için bk.: R. Meiggs, The Athenian Empire, Oxford, 1972, s.155 v.d; P.J Rhodes, "The Delian League: The Mid-Century Crisis", Cambridge Ancient History, vol.5., 2.nd ed., Cambridge, 1992, s.34-6; D.M Lewis, "The Thirty Years Peace", Cambridge Ancient History, vol.5., 2.nd ed., Cambridge, 1992, s.121-127.

${ }^{9}$ Atina İmparatorluğu'nun ideolojik yaylmacılığa dayalı felsefesi ile ilgili inceleme için bk. Bowra, a.g.e, s.106-138.

${ }^{10}$ Ideolojik yaylmacılık ve kontrole dayalı soyut nitelikli bir psikolojinin bir tarihi olaya yol açmasının bilimsel olmadığı savunulabilir. Fakat bu türden bir düşünce tarihi bir yanılgı olur. Antik Çağ'da sırf intikam, kibir, ōzgürlūk, şeref duygusu gibi duygusal, ahlâki değerler ve dini 
zenlendiği zamanda ekonomik zorunluluk yukarıda aktarılan metinde geçen diğer fetihler arzusu için ana sebep olmuş olsayd,, Plutarkhos muhtemelen bundan da söz ederdi. Daha sonra Peloponnesos Savaşı sırasında (M.Ö. 431-404) gerekli kaynaklardan yoksun oldukları zaman Atinalılar'ın öncelikleri tekrar ekonomik çıkarlar üzerine yönelecekti.

Plutarkhos'un bahsettiği gibi Atina'nın siyasî güç ve ekonomik refahının zirvesinde olduğu bir dönemde Perikles, temelde acil, zorunlu siyasî ve ekonomik çikarlar elde etmeye dayanmayan fetihler düzenlemek isteyen Atina halkının bu düşüncesini kırmaya, yabancı devletlerin işlerine karışma arzusunu frenlemeye ve halkının güçlerini kazanmış olduklarını savunmaya yönlendirmeyi amaçlamış olabilirdi ${ }^{11}$. Eğer Atinalılar daha fazla

nedenlerle birçok tarihi olayın meydana geldiği unutulmamalıdır. Örneğin, Herodot Tarihìnde geniş bir şekilde anlaulan. G. Rawlinson, trans., Herodotus, The Histories, London, 1992. VII.kitap. M.Ō. 480'li yıllardaki Hellas'in istilasını Kserkses, sırf intikam ve kibir nedeniyle gerçekleştirmiştir. Bu konu ile ilgili diğer birçok örneğin bulunabileceği çalışmalar için bk.: J.M Bryant, Moral Codes and Social Structure in Ancient Greece: A Sociology of Greek Ethics from Homer to the Epicureans and Stoics, New York, 1996; N.R.E Fisher, Hybris: A Study in the Values of Honour and Shame in Ancient Greece, Warminster, 1992. Ozellikle Atina fetihlerinin sebeplerinden olan olan güç ve zaferin önemi için bakulacak çalı̧̣malar: De Romilly, a.g.e, s.65-82 ve A.W.H Adkins, Moral Values and Political Behaviour in Ancient Greece, London, 1972, s.133-9.

${ }^{11}$ Scott-Kilvert, a.g.e, Perikles.21 v.d. Diğer taraftan Doğu Akdeniz ve Ege'deki Atina ticaret ürünlerinin dağıtım şemasının (özellikle seramik ) Atina'nın bu dỏnemde ekonomik ilişkilere girdiğini gỏsterdiği önerilebilir. Fakat arkeolojik buluntular ile Atina devleti'nin ekonomik ve politik yayılmacılığı (kolonileşme) arasında kesin bir ilişki kurulamaz. Günümūz anlayışı ile eskiçağ șehir devletlerinin kâr elde etmek amacıyla doğrudan ticaretle uğraşıp muhtemel rakiplerini elediklerini, tüccarları destekleyip onlara kredi verdiklerini, ticari bir donanmaya sahip olduklannı, kendilerinin üretime katkuda bulunduklann, ticari tekeller elde etmek istediklerini v.b., düşünmek bir tarih şaşması (anakronizm) olabilir. Eskiçağda şehir devletleri genel olarak ticari kâr amacı düşūnmeden sadece ihtiyaç duydukları zamanlarda hububat veya kereste gibi temel gereksinim maddelerinin ithali ile uğraşmaktaydılar. Atina'da seramik üretimi ózel şahısların elindeydi. Bu seramiklerin ve onların içinde taşınan malların ihracau devletin herhangi bir müdahelesi olmadan kendi ticaret gemilerine sahip tüccarlar tarafindan yapılmaktaydı. Günūmüze kadar gelmiş olan deliller de Atina ticaretinin būyük çoğunlukta dĭ̌er Hellen şehir devletlerinden yabancı tūccarlar tarafından yürütüldūğünū ortaya koymuştur. Bu sebeple, Akdeniz, Ege ve Karadeniz çevresinde bulunan Atinalılar'a ait seramikler Atina devleti'nin bu bölgelerde siyasî ve ekonomik olarak etkili olduğunu kesin olarak gōsteremez. Konuyla ilgili çalışmalar için bk.: B.L Bailey, "The export of Attic Black-Figure Ware", Journal of Hellenic Studies, nu.60, 1940, s.65; T.J Dundabin, The Western Greeks, Oxford, s.241-243; M.M Austin and P. Vidal-Naquet (trans.), Economic and Social History of Archaic Greece: An Introduction, Berkeley, 1977, s.113115; Y. Garlan, "Greek amphora and trade", Trade in the Ancient Economy, eds., P. Garnsey, K. Hopkins ve C.R Whittaker, London, 1983, s.27-35; C.M Reed, Maritime traders in the Greek World of the Archaic and Classical Periods, Oxford, 1980. Bu bağlamda vurgulanması gereken bir diğer nokta ise Peloponnesos savaşından önce Atinalılar'ın imparatorluklarının zirvesinde olduklan bir dönemde Karadeniz'den herhangi bir temel gereksinim maddesi ithal ettiklerine veya etme ihtiyacında olduklarına dair herhangi bir delilin olmamasıdır. Bk.: P. Garnsey, Food and Food Supply in Graeco-Roman World: Responses to Risk and Crisis, Cambridge, 1988, s.123; D. Braund, "The Luxuries of Athenian Democracy", Greece and Rome, vol.41, nu.1, April 1994, s.41-42. Bütün bu noktalar gòz ònūne alındı̆̆ında, Perikles'in hububat gibi sırf temel gereksinim malları temin etmek için bu būyük seferi dūzenlemiş olabileceği dũşūnūlemez. 
servete ihtiyaç duymuş olsalardı, Perikles bu düzenlenmek istenen fetihlerin sonucunda ortaya çıkacak pratik faydalardan Atinalılar'ı yoksun bırakmayı düşünmezdi. Atina vatandaşları, M.Ö. 449 yılında Persler ile imzalandığı görülen Kallias antlaşmasını ${ }^{12}$ göz ardı ederek Pers devletine doğrudan saldırmak istediklerinde Perikles vatandaşların duygularını dizginlemek isteyip, onların ilgilerini başka yere çekmeye gerçekten ihtiyaç duyabilirdi. Perikles bu sayede Karadeniz Seferi'ni düzenleyerek Misır ve fethedilmesi zor diğer bölgelere yönelik Atinalılar'ın şiddetli arzularını gidermiş olacaktt.

Karadeniz'in seçilmesinin Atina İmparatorluğu'nun tabiatından kaynaklanması muhtemeldir. Bu İmparatorluk deniz gücü üzerine kuruluydu. Plutarkhos, Perikles'in birçok vatandaşın sekiz aylık ücretle hizmet edip aynı zamanda denizciliği uygulayı öğrendiği altmış tane triremesi heryıl sefere gönderdiğini ve bunu da sırf Atina halkını hoşnut bırakmak için yaptığın bildirmektedir ${ }^{13}$. Atinahlar'ın Perikles'den önce firtınalı, kıyılarının bir kesimi keskin kayalıklardan oluşan ve geniş çaplı korsanlık olayları ${ }^{14}$ yaşanan Karadeniz'e sefer düzenlediğine veya herhangi bir koloni gönderdiğine dair bir delil de yoktur. Böylelikle Atina gücünün dorugunda iken Perikles meydan okuma anlamında Atina donanmasının Karadeniz'de bile hakimiyeti sağlayabilecek kapasitede olabileceğini göstermek istemiş olabilirdi. Aynı zamanda Atinalılar bölgenin Krallık ve Prenslik' lerine güçlerini gösterecekler ve onlar tarafından da tanınacaklardı. Muhtemelen Persler'in Karadeniz'e yönelik ilgisi zayif olduğundan, ${ }^{15}$ bu sefer doğrudan doğruya onların tepkisine yol açmayacakt.

Karadeniz seferi ile bir güç gösterisinde bulunma arzusu tabi olarak seferin gelişim sürecinde Atinalılar için bazı başka ekonomik ve politik çıkarlar da sağlayacaktı. Sefer ile ilgili yukarıda aktarılan gözleminin birinci cümlesinde Plutarkhos, Perikles'in bu sefer sırasında diğer Hellen şehirlerine iyi davranıp onların arzuladığı antlaşmalar yaptığını bildirmektedir. Plutarkhos'un bu gözleminden Atinalılar'ın tamamıle tek taraflı olarak

12 Kallias antlaşması ile ilgili çalışma için bk.: Lewis, a.g.m.

${ }^{13}$ Scott-Kilvert, a.g.e., Perikles.11.3-5

${ }^{14}$ Karadeniz'deki bu yaygın korsanlık olaylarından Tsetskhladze'nin yaptuğı gibi Perikles'in Hellen şehirlerine ve tüccarlarına musallat olan korsanlara karşı yardım etmek istediği için böyle bir seferi dūzenlediği sonucunu çıkarmamalıyız. Tsetskhladze, a.g.e.,s.462-3. Kısa süreli ve bir defalık bir sefer uzak bir bölge olan Karadeniz'de korsanlığın kōkünün kazınmasına pek faydalı olamazdi.

${ }^{15}$ Persler'in Karadeniz Bölgesine ilgisinin zayıflı̆̆ı için bk.: Braund, Georgia in Antiquity: A History of Colchis and Transcaucasian Iberia 550 BC-AD 562, Oxford, 1994, s. 124. 
fedakarlık yaparak bu şehirlere yardımda bulunduğu sonucu çıkarılabilir. Fakat bizce bu noktada Plutarkhos Hellen birliği fikrini ön plana çıkararak konuyu abartmakta ve bizleri bir dereceye kadar yanlı̧ yönlendirmektedir. Bu iyilikleri yaparken Atinalılar'ın kendi çıkarları için kontrol mekanizmalarını tam olarak durdurduğu söylenemez.

Plutarkhos Perikles'in antlaşmalar yapmış olduğu Karadeniz'deki çeşitli Hellen şehirlerinden ve bu antlaşmaların içeriğinden bahsetmektedir. Ancak aşağıda belirtileceği gibi Plutarkhos gözlemlerinde sadece sefer s1rasında Atinalılar'ın Sinop'a müdahelesine yer vermektedir. Bu da sefer öncesinde planlanmış bir müdaheleden çok Perikles'in pragmatik düşünüşlü olması nedeniyle sefer sırasında meydana gelen bir gelişmeyi Atinalılar'ın siyasî çıkarı için kullanmak istemesinden kaynaklanmış gibi görünmektedir.

Plutarkhos Sinop tiranı Timesilaus'a karşı yardım etmek için Lamakhos'un kumandası alunda bir kara gücü ve 13 savaş gemisi ile beraber Timesilaus tarafından önceden sürülmüs bir grup insanı Perikles'in Sinop'ta bıraktığını bildirmektedir. Tiran ve onun destekçileri şehirden sürüldükten sonra, Perikles Atina'ya döndüğünde meclisten bir kararname çıkarmıs ve bu kararname ile 600 Atinalı gönüllünün Sinop'a yelken açmalırını ve önceden tirana ve destekçilerine ait olan ev ve toprakları kendi aralarında bölerek yerleşmelerini sağlamıştır ${ }^{16}$. Göründüğü kadarı ile Timesilaus Atinalılar'la işbirliği yapan bir grup politik hasımını sürmüştü. Eğer bu sürgün edilenler Atina'ya yardım için gelmemişlerse, ${ }^{17}$ Perikles'in Karadeniz'de bulunma firsatundan yararlanıp askeri yardım umabilirlerdi.

En önemli nokta Atinalılar'ın seferden önce Sinop'u ele geçirmek gibi kesin bir amacının olmayabileceğidir. Sefer sırasındaki bu beklenmedik gelişmeden dolayı, Perikles'in kendisinin elindeki büyük güçle doğrudan olarak müdahele etmektense muhtemelen başarılı olabileceklerini düşünerek Sinop muhalefetini desteklemek için buranın çevresinde gerektiğinden daha az güç bıraktuğı ve kendisinin geri döndüğü görülmektedir. Daha

${ }^{16}$ Scott-Kilvert, a.g.e., Perikles.20.3

${ }^{17} \mathrm{Bu}$ sürgün edilenler Atina'ya yardım istemek için gelmiş olsalar bile, bunun Karadeniz Seferi'nin düzenlenmesi için gerçek dürtüyü oluşturmuş olabileceğini zannetmiyorum. Göründūğŭ kadarı ile Perikles'in kendisi Timesilaus'u tahtundan indirmek için uğraşmadı. Aynı zamanda bu seferin kendisi sadece Sinop'tan ziyade Karadeniz civarındaki değişik şehirleri kapsamıs gõrünüyor. 
sonra başarılı olduklarını görünce bir kararname çıkarturarak buraya Atinalı gönüllüler göndermiștir.

Plutarkhos M.Ö. 450'den hemen önceki ylllarla ilgili gözlemlerinde Atinalılar'ın değişik yerlere klēroukhialar ${ }^{18}$ gönderdiğini bildirmektedir ${ }^{19}$. Plutarkhos'un Sinop'a özellikle "Atinalı gönüllüler" (Athênaiôn ethelontas) gönderildiğini yazması bu gönderilen kişilerin tam anlamıyla yoksul olmayıp kendi demokratik rejimlerini, dolayısıyla kendi hayat tarzlarını buradaki halka empoze etme niyetinde olan insanlar olduğunu önerebilir. Bu gönüllüler Sinop'ta yaşayan Atina destekçisi yerel halkla beraber tiran ve destekçilerinden istimlak edilen toprak ve evlere yerleştirildi ve kimileri nihayetinde burada Atina'dan daha iyi hayat şartlarına sahip oldular. Muhtemelen şehirde bir çeşit garnizon olarak görev yaparak Atina sempatizanı demokratik rejimi desteklemeye devam ettiler. Sonuçta Perikles'in bu firsatu değerlendirmedeki siyasî amacı Sinop'un da demokratik rejimin getirilerinden yararlanmasını sağlamak olabilirdi ${ }^{20}$. Fakat aynı zamanda Sinop uzun vadede meydana gelebilecek büyük bir savaş zamanında ihtiyaç duyulduğunda Atina devletine temel gereksinim maddeleri ve siyasî destek sağlayabilecekti ${ }^{21}$.

${ }^{18}$ Klëroukhia: Fethedilmiş toprakların bir parçasının klēros bağışlandığı yerleşim birimine gönderilen ve buralarda yaşayan genellikle fakir Atina vatandaşları.

${ }^{19}$ Scott-Kilvert, a.g.e, Perikles. 11.5-6.

20 Thukydides'in "Peloponnesos Savaşı" adlı eserinde geçen bu savaşta ilk kez ölenlerin anısına düzenlenen cenaze tơrenindeki konuşmasında Perikles "Biz iyilik yaparsak, bunu şıar veya kayp hesabı ile yapmayz; biz bu iyilikleri gerisini düşünmeden serbest özgürlüğümüze dayanarak yaparız." iddiasında bulunuyor. Crawley, a.g.e., II.kitap, 40.4. Perikles daha sonra şōyle konuşur: "Bizim maceracı ruhumuz bizi her denize ve her toprağa girmeye zorladi; ve biz heryerde dostlanmıza yapılan iyiliklerin ve düşmanlanmıza çarptırdığımız cezalann sonsuza kadar sürecek hatıralarını bıraktuk." Crawley, a.g.e. II.kitap, 41.4 . Bu sōzlerden Atinalılar'ın sırf kendi demokratik sistem ve hayat tarzların empoze ederek dost şehirlerin bunların nimetlerinden yararlanmalannı sağladıklanı ve onlara tek taraflı olarak yardım ettikleri gibi bir sonuç çıkarılmak istenebilir. Fakat Atina devletinin idealleştirilmiş bir şeklini ortaya koyduğundan bu cenaze tōreninde yapılan konuşmalar abartılı olabilirdi ve biz bunları yorumlamada dikkatli olmalıyı. De Romilly, a.g.e, s.147. Buna rağmen, Karadeniz Seferi'nin düzenlendiği dönemde ekonomik refah ve siyasî gựcünün zirvesinde olan Atina devleti fazla bir siyasî ve ekonomik çıkar gōzetmeden kendi demokratik sistemini ideolojik olarak yayma eğilimine girmiş olabilirdi. Aynı zamanda Miletliler'in M.Ō. 440 ylındaki Samos ayaklanmasına katkıda bulunmaları ve Karadeniz'deki kolonilerinin çokluğu nedeniyle Atinalılar, rekabet amacıyla Karadeniz'de kendi sempatizanlan hükümetlerin oluşmasını sağlayacak firsatlan değerlendirmek isteyebilirlerdi.

${ }^{21}$ Perikles in niyetinin acilen Sinop şehrinin kaynaklarını sōmürmek olduğu kanısında değilim. Tercihini Sinop yerine daha iyi bir limana ve tabi kaynaklara sahip olan Trabzon üzerine yapabilirdi. Trabzon ve çevresinin tabi kaynaklanının zenginliği için bk.: R. Stoneman, Across the Hellespont: A Literary Guide to Turkey, London, 1987, s.207-220. Ayrica Sinop için bk.: B. Basoğlu, Sinop İli Tarihi, Ankara, 1978 ve P.M Bijiskyan, Karadeniz Kıyları Tarih ve Coğrafyası, İstanbul, 1969, s.28-31. Sinop için ilk el kaynak olarak bk.: A. Pekman (tercüme), Strabon, Antik Anadolu Coğrafyası, Arkeoloji ve Sanat Yayınları, İstanbul, 1993, XII.kitap, 3.11 ve R. Warner (trans.), Xenophon, The Persian Expedition, London, 1972, Anabasis.V.kitap, 5.7; VI.kitap, $1.10,15$. Uzun surların inşaatunın bitmesiyle Atina halku Perikles'in tavsiyesine uyarak Peloponnesos savaşı sırasında Attika'y boşaltup surların içine çekilerek savunmaya dayalı bir strateji izledi. Peloponnesoslular Attika'y işgal ettiler ve nihayetinde Atina devleti tamamıle dış denizlerden gerekli malların ithaline bağımlı hale geldi. Bk.: G.L Cawkwell., "Thucydides' judgement of Peric- 
Aynı zamanda Amisos' (Samsun) da bir Atina yerleşiminin kurulma ihtimali de vardı. M.Ö. 4.yüzyıl tarihçisi Khios'lu Theopompus'a göre bu yerleşim birimi Miletliler tarafindan kurulmuştur. Kapadokyalılar'ın kontrolündeki bir dönemden sonra Athenokles ve ismini Piraeus'a çeviren Atinalılar tarafindan kolonileştirilmiştir ${ }^{22}$. Ayrıca bu şehrin Piraeus olarak tekrar isimlendirildiğini gösteren M.Ö. erken 4.yüzylla ait sikkeler vardır ${ }^{23}$. M.Ö. 70 ylında Karadeniz şehirlerinin siyasî yapısının yeniden düzenlenmesi aşaması bağlamında Appian şöle söz eder: "Roma generali Lukullus aynı şekilde deniz yolu ile kaçan Amisos vatandaşlarını tekrar evlerine yerleştirdikten sonra onlara yakınlık duydu ve Atina halkına Alexander tarafindan gösterilen lütfu taklit etme gayreti ile şehre bağımsızhğını bahşetti ve vatandaşlarını hızla geri çağırdı. Çünkü bunların Atinalılar'ın deniz imparatorluğu zamanında Atina tarafindan yerleştirilmiş olduğunu ve başlangıçta demokratik bir hükümete sahip olup daha sonra uzun bir süre için Pers Kralları'na bağımlı kalmış ve nihai olarak demokrasilerinin Alexander tarafindan bir kararname ile restore edilmiş ve en son olarak Karadeniz Kralları'na hizmet etmek zorunda bırakılmış olduklarını ögrenmişti. "24 Bundan anlaşıldığı kadarıyla şehrin nüfusu boşalmış ve tekrar Atinalılar tarafından arturılmışt. Bu şehrin Atinalılar tarafından yerleşim tarihi karanlıktır. Fakat Pers ve Peloponnes Savaşları arasında bir tarih önerilebilir. Atinalılar Amisos'a Perikles'in seferi sonucunda yerleştirilmiş olabilirdi. Çünkü İskenderiye'li eski Roma tr. ihçisi Appian(M.S. ca. 150) tarafından yukarıda işaret edildiği gibi Atina vatandaşları "Atina denizlere hakim olduğu zaman" yerleştirilmişti. Muhtemelen Athenokles ${ }^{25}$ isminde bir tirandan alınmış ve Atina vatandaşları şehre getirilip önceki Atina karş1t yerleşimcilerden istimlak edilen topraklara yerleştirilmiştir. Böylece bu şehirde Sinop örneğini takip etmiş gibi görünmektedir.

lean Strategy", Yale Classical Studies, vol.24, 1975, s.53-70. Bu dönemde Atina devleti nispeten uzak ve tehlikeli olmasına rağmen Karadeniz sehirlerinden de temel gereksinim malları ithal etme ihtiyacı duymus olabilirdi.

22 F. Jacoby, Die Fragmente der griechischen Historiker, Berlin and Leiden, 1923-, Theopompus 115 F 389: bu aynı zamanda Pekman, a.g.e., XII.kitap, 3.14 de bahsediliyor. Bölgenin zenginliği ve gūzelliği için bakulacak çalışma: A. Sarcan, Samsun Tarihi, Ankara, 1966. Diğer taraftan bu şehrin iyi bir limanı olabilirdi. Çünkü Atina'nın o zamanda meşhur limanı olan Piraeus ile aym ismi tasımaktadır. figure.5.

${ }^{23}$ B.V Head, Historia Numorum: a manual of Greek numismatics, Oxford, 1911, nu.496.

${ }^{24} \mathrm{H}$. White (trans., Loeb Classical Library), Appian's Roman History, Cambridge, 1912 1913. Mithridateios. 83. mektedir.

${ }^{25}$ Mattingly ( a.g.m., s.154) Athenokles isminin Atina'da çok az bulunduğuna işaret et- 
Sinop tiranının tahtından uzaklaşturılması olayında olduğu gibi Perikles, ummadiğı fakat bu sefer sonucunda ortaya çıkan firsatlardan en üst düzeyde yararlanmayı amaçlamıştı. Fakat elimizdeki yetersiz kaynaklar göz önüne alındığında, Atinalılar'ın Karadeniz çevresindeki sadece birkaç şehrin iç güvenliklerinden kaynaklanan problemlerini bahane ederek Atina sempatizanı demokratik hükümetlerin oluşumunu sağladıkları görülmektedir. Bu firsatların değerlendirilmesi ilk safhada Atina'nın demokratik rejimini ve hayat tarzını siyasî olarak yaymaya yönelik bir ideolojinin sonucu olarak görülebilir. Fakat uzun vadede Atina'nın ekonomik çıkarlarına da hizmet edebilirdi.

Bütün bunlara rağmen Karadeniz Seferi sonucunda elde edilen siyasî ve ekonomik çıkarların gerçekte çok önemli olmadığı anlaşılmaktadır. Perikles'in bu sefer sırasında ziyaret ettiği iddia edilen bütün şehirlerden vergi topladığına dair hiç bir delil yoktur. Sinop ve muhtemelen Amisos gibi güvenliğini sağladığı șehirlere vergi uygulayıp uygulamadığı da bilinmemektedir. Ĕger bu iki şehir sefer sonucunda (M.Ö. 436/5) Attika-Delos Deniz Birliği'ne katılmış olsalardı, Peloponnesos Savaşı öncesi Birliğin "vergi listeleri"nde ${ }^{26}$ görülürlerdi.

Diğer taraftan Karadeniz'den şehir isimleri ilk kez Birliğin M.Ö. 425/4 yılında değerlendirilen vergi listesinde ortaya çıkmaktadır ${ }^{27}$. Bu yıldaki değerlendirmenin yazılı olduğu kitabenin günümüze kadar gelip restore edilmiş fragmenterlerinden bu değerlendirmenin Thudippus tarafindan meclise sunulan kararname sonucunda yapıldığı görülmektedir. Bu kararname kuvvetli dili ile göze çarpar. Önemi ise vergi miktarlarını iki-üç kez artturması ve vergi ödeyebilecek bütün şehir devletlerini listelemesidir ${ }^{28}$. Yüksek miktardaki bu verginin acilen toplanmasını gerektiren nedenler arasında savaş için para toplanması ve Kleon'un bu kaynağı kendi finansal çıkarları için kullanmak istemesi bulunmaktadır ${ }^{29}$. Listedeki bazı şehirler

${ }^{26}$ Muhtemelen M.Ō. 454 ylında, Attika-Delos Deniz Birliği'nin hazinesi Atina şehrine taşındıktan sonra Atinalılar müttefiklerinden almış oldukları vergi miktarlarını kitabelere listeler halinde kaydetmişlerdir. Bu konuda bk.: B.D. Meritt, H.T Wade-Gery, ve M.F McGregor, The Athenian Tribute Lists, 4 volumes: I, Cambridge ( Mass. ) 1939; II-IV, Princeton 1949-1953.

${ }^{27}$ Meritt ve diğerleri, a.g.e., 1.A9, s.154-7; 2.A9, s.40-3; C.W Fornara, Archaic times to the end of the Peloponnesian War, 2.nd ed., Cambridge, 1983, nu.136.

${ }^{28}$ Meiggs, a.g.e., s.327.

${ }^{29}$ Kleon'un politik karşıtlanı onun kendi politik çıkarı için insanları sõmürmeye hakkı olmadığı fikrindeydiler. Scott-Kilvert, a.g.e., Aristides.24.3. Bu kararnamenin meclisten geçmesinde rol oynayan Thudippos Kleon'un kızıyla evlenerek çocuklanndan bir tanesine kayınpederinin ismini vermiş olabilirdi. Bk.: R. Meiggs ve D.M Lewis, A Selection of Greek Historical Inscriptions, Oxford, 1969, nu.69, s.197. Bu konuda bakulacak çalışmalar: M.F McGregor, "Kleon, Nikias and the Trebling of the Tribute", Transactions of American Philological Association, 1935. 
Atina'dan çok uzaktaydı ve vergi toplamak çok uzun zaman alabilirdi. Bunu yapmak büyük bir gayret ve kaynak gerektirdiğinden bütün şehirlerden her yll vergi toplanmayabilirdi. Hatta bunu yillara yaymak zorunda kalabilirlerdi ${ }^{30}$. Bu sebeple Atinalılar'ın M.Ö. 425/4 yllında listeleri mümkün olduğu kadar geniş tutma ihtimalleri vardı. Kleon'un gerçekçi olmayan miktardaki bu vergiyi pratikte toplamış olabileceği de şüphelidir. Gerçi şehirlerin isimlerinin çok küçük bir kısmı yeniden restore edilip okunmaya çalışılmışsada, Karadeniz'in Kuzey ve Güney kıyılarından bir çok şehre de bu yllın vergi listelerinde yer verilmiştir ${ }^{31}$. Aynı şekilde bu yüksek sayıdaki Karadeniz şehrine hayali bir şekilde propaganda yapmak için listelerde yer verilmiş olabilirdi ${ }^{32}$.

Sonraki basamak bu durumdan memnun olmayan Birlik üyesi devletlerin karşı koymasına rağmen Atinalılar'ın vergi toplamaya devam etmesi olacakt $^{33}$. Thukydides Lamakhos'un M.Ö. 424 yılının yazında 10 gemi ile Karadeniz'e açıldığından söz etmektedir. Fakat Lamakhos "Herakleia [Karadeniz Ereğlisi] toprağında Calex nehrine demirlediğinde kısa sürede meydana gelen su baskını nedeni ile gemilerini kaybetti. Kendisi boğazların berisinde Asya da yaşayan Bithynia Trakyalılar'ın toprakları arasından yaya olarak gitti ve Karadeniz'in ağzında Megara kolonisi olan Kalkhedon [Kadıköy]' a ulaştu." ${ }^{34}$

Atinalılar göründüğü kadarı ile uzaklığı, firtınalı havası, çevresinde barbar kabile ve korsanların bulunması sebebi ile bu bölgeden vergi toplanması zorluklarını düşünerek Perikles'in Karadeniz seferi sırasında bölgeyi tanımış ve muhtemelen oradaki şehir ve kabilelerle bazı dost ilişkileri olmuş Lamakhos'u vergi toplamak için Karadeniz'e göndermeyi uygun buldular. Buna rağmen yukarıda aktarılan Thukydides'in gözleminden Lamakhos'un tabi nedenlerden dolayı bu vergi toplama işinde tam olarak başarılı olamadığı görülmektedir.

s.146-164; B.D Meritt ve H.T Wade-Gery, "Pylos and the Assessment of Tribute", American Journal of Philology, nu.57, 1936, s.377-394; B.J Meritt, "Kleon's Assessment of Tribute to Athens", Classical Contributions- Studies in Honour of McGregor Malcolm Francis, eds. G.S. Shrimpton and J.J McCargar, New York, 1981, s.89 v.d.

${ }^{30} \mathrm{Bu}$ yüksek miktardaki verginin toplanması karşısında rastlanan zorluklar için bk.: J.B Bury ve R. Meiggs, A History of Greece to the death of Alexander the Great, 4.th ed., London, 1975, s.239 ve R. Sealey, A History of the Greek City States, 700-338 B.C, Berkeley, 1976, s.336

${ }^{31}$ S. Dow, "Studies in the Athenian Tribute Lists III", Transactions of American Philological Association, 1941, nu.72, s.78 ve H.B Mattingly, "Discussion of the problem of dating certain Attic texts of the 5 th Century B.C ${ }^{n}$. Annual of British School at Athens, nu.65, 1970, s.140 v.d.

${ }^{32}$ Meritt v.d, a.g.e., II, s. 345 ve Sealey, a.g.e., s. 336-7.

${ }^{33}$ Yüksek miktardaki bu verginin insafsız olarak uygulanması imparatorluğun bir çok yerlerinde ayaklanmalara neden olmuş gibi görünmektedir. Crawley, a.g.e., IV.kitap, 30.1; 75.1.

${ }^{34}$ Crawley, a.g.e., IV.kitap, 75.2 
Gerçekte Herakleia (Karadeniz Ereğlisi) M.Ö. 425/4 yllında değerlendirilen Attika-Delos Deniz Birliği'nin vergi listelerinde ismi restore edilebilen sadece iki şehirden biridir ${ }^{35}$. Önemli olan nokta İstanbul Boğazı'na yakın olmasıdır. Bize göre Lamakhos kısa mesafeli bir harekatta bile başarılı olamadıktan sonra, Atinalılar'ın Karadeniz'in daha uzak ve bilinmeyen bölümlerinden nasıl vergi toplanabilmiş olabileceklerinin tekrar düşünülmesi gerekir. Ayrıca Herakleia vatandaşlarının kolaylıkla vergi ödemeye boyun eğmediklerine dair kanıt da vardır ${ }^{36}$. Atina İmparatorluğu'nun dağılma süreci olan M.Ö. 5.yüzyıl sonlarında Herakleia ve özellikle Sinop'un Karadeniz'in geniş sularına hakim olduğunu ve güçlü olduklarından diğer Hellen şehir devletlerinin isteklerine boyun eğmediklerini de görüyoruz ${ }^{37}$. Atinalılar özellikle Peloponnesos Savaşı sırasında (M.Ö. 431-404) Byzantion'un ötesine seyeredemeyecek kadar meşğul olduklarından Herakleialılar güçlerini kolaylıkla Atinalılar'a karşı vergi ödememek için kullanabilirlerdi.

Özetlemek gerekirse Karadeniz şehirlerinden vergi toplamanın Perikles'in Karadeniz Seferi'ni düzenlemesi için bir neden oluşturduğu söylenemez. M.Ö. 436/5 yılından sonrada Atina devletinin başarılı bir şekilde bu bölgeden vergi topladığına dair kesin bir delil yoktur. Bu gözönüne alındığında, Atinalılar'ın M.Ö. 5.yüzyılda Karadeniz Bölgesi'ndeki egemenliği Perikles'in kısa süreli bir güç gösterisinden daha ileri gidememiştir. Plutarkhos dışında hiç bir eskiçağ yazarı bu seferden söz etmez. Eğer bu sefer Atina İmparatorluğu'nun büyümesine gerçekten önemli bir katkı sağlamıs olsaydı, Thukydides bundan Pentēkontaetia ${ }^{38}$ sında söz ederdi.

\section{SONUÇ}

M.Ö. 436/5 yilında siyasî güç ve ekonomik refahlarının zirvesinde olan Atinalılar ne kadar güçlü ve şöhretli olduklarını dünyaya gösterme arzusundaydılar. Bu psikoloji içinde acil, gerekli siyasî ve ekonomik çıkarlar

${ }^{35}$ Tsetskhladze, a.g.m., s.464-5

${ }^{36}$ Warner, a.g.e., Anabasis.VI.kitap, 2.1-10. Aynı şekilde Sinop için bak:Warner, a.g.e., Anabasis.V.kitap, 6.21

${ }^{37}$ Sinop için bk.: Warner, a.g.e, Anabasis.V.kitap, 3.2-3, 7-8, 11, 13, 24-5; VI.kitap, 1, 10-13, 15, 19, 21, 26, 31. Herakleia için bk.: Warner, a.g.e., Anabasis.V.kitap, 6.10; VI.kitap, 1.33, 2.1, 19 , $3.14,4.1-3,13,5.1$.

38 Pentēkontaetia: Thukydides'in 'Peloponnesos Savaşı' adlı eserinde Pers Savaşlan ile Peloponnesos Savaşı arasında Atina devletinin nasıl büyüyüp imparatorluk haline dōnüştüğủnū anlatığ1 50 ylllkk dōnem. 
gözetmeden Misır, Sicilya, Etruria ve hatta Kartaca'yı da kontrol ederek kendi ideolojilerini empoze etmek isteyen Atina halkının bu arzularını kırmak için Perikles nispeten gereksiz insan ve emek kaybına yol açmayacak Karadeniz seferini düzenlemiş ve güç gösterisinde bulunmuş olabilirdi. Diğer taraftan, bu seferle Perikles'in Hellen şehirlerine çok iyi davrandığı ve tek taraflı olarak onların lehinde bazı yerel antlaşmalar yaptığına dair Plutarkhos'un gözlemlerinde muhtemelen bir abartma olduğu görülmektedir. Zorunlu olmasa da bu sefer sırasında ve sonrasında ortaya çıkacak siyasî ve ekonomik firsatlan Perikles'in değerlendirmesi doğaldır. Fakat bu pratik faydaların gerçekte fazla önemli olmadığı görülmektedir. Elimizde bulunan kısıtlı deliller, Atinalılar'ın çıkan firsatları değerlendirerek ideolojik olarak sadece Sinop ve muhtemelen Amisos'da kendi sempatizanı demokratik rejimlerin oluşmasına yardım ettiklerini göstermektedir. Bu iki şehir sefer sırasında zorunlu olmasa da gelecekte büyük bir savaş s1rasında ihtiyaç duyulduğunda Atina devletine bazı temel gereksinim mallan ithal edebilir ve siyasî destek sağlayabilirdi. Ancak Karadeniz gibi uzak ve tehlikeli bir bölgeden savaş sırasında ithalatun Atinalılar için ne kadar zorunlu ve önemli olabileceğinin de sorgulanması gerekir. 